\title{
THE ROLE OF THE SOCIAL WORKER TO EMPOWER FAMILIES IN A DEEP RURAL COMMUNITY
}

\section{Corinne Strydom, Cornelia Wessels, Herman Strydom}

\section{INTRODUCTION}

A research study was conducted at Heuningvlei near Vryburg in the Northern Cape Province of South Africa during 2006. The study was called "Tshwaragano", meaning togetherness, and was sponsored by the National Research Foundation. The research focused on health issues and poverty, and was undertaken to determine their effect on families in rural areas. Seven master's students and two PhD students were involved in the project. The master's students did a needs assessment with their specific aim in mind and developed guidelines. The $\mathrm{PhD}$ students used this needs assessment of the first phase to compile their social work group-work programmes to empower the families of Heuningvlei and to enhance their quality of life. This article reports on a section of the research which examined the living conditions and income of the households, and the causes and effects of poverty and unemployment. Aspects such as crime, violence and marital conflict received attention. Because the strengths approach was used in this study, the strengths of the families were investigated. Finally, the roles of the social worker to implement preventive and treatment strategies in the community were discussed.

\section{PROBLEM STATEMENT}

South Africa is experiencing a situation of escalating mass poverty, which also is one of the most problematic social problems the country has to deal with. According to Patel (2005:52), poverty is one of the greatest challenges of Southern African countries. Here the worst poverty is to be found in rural areas, which are frequently economically depressed. A report on poverty reveals that $71 \%$ of the poor population of South Africa live in rural communities (Msindisi, 2000:5; White Paper for Social Welfare, 1997). This disturbing figure indicates that the rate of impoverishment in the rural communities of South Africa is alarming and leaves much to be desired. To many rural people the environment and natural resources are the key to their livelihood, and land, agriculture and livestock are often seen as forming the backbone of development. However, the rural households face a number of challenges, including macroeconomic policies that result in higher food and transport prices, retrenchment, chronic illness which increase expenditure on medical bills and funerals, poor agricultural practices and environmental degradation, and isolation from support services for advice, inputs, etc. (Barnett \& Blaikie, 1992:34; Wessels, 2003:61).

Families have the capacity for growth and change. They also have many capabilities, abilities and strengths (Saleebey, 2002:254). To understand families one needs to systematically examine their survival skills, abilities, knowledge, resources and desires that can help them.

Although the structure of families changed in the $21^{\text {st }}$ century, the family "still is that intimate place where fragile, tiny human beings have the best chance to sprout into hardy blooms; where adults can find appreciation, and comfort, and where they can exercise and have their sexuality affirmed; and where elders can gather together the remnants of their life and stitch them into sage advice and comforting activity" (Saleebey, 2002:265). The family is the base from which the members can venture out into, and make a contribution towards, a wider world of people and the community they belong to. 
The tough economic times and the growing number of people in South Africa living in poverty also play a significant role in the composition of a family. Many families in South Africa are troubled by poverty, crime and HIV/Aids (Wessels, 2003:60). Black families in South Africa face a seemingly endless series of challenges, but for many years they have had no resources, knowledge, skills or competencies to call on in times of distress. Although these families had nothing, they survived and somehow had capacities they used for striving towards their aspirations, solving their problems, meeting their needs and enhancing the quality of their lives. Ryke, Strydom and Botha (2008:23) and Saleebey (2002:1-12) write that all people have innate wisdom and capacity for transformation, even in the midst of conditions of pain and suffering. Human beings can generate their inherent goals and visions for a better quality of life, and in so doing transform their world. Family problems are real and have an impact on every member of the family. Although the migrant labour system of the past had a dramatic impact on family life, families survived. They took steps, summoned up resources and coped. We need to know how these families managed and what resources provided strength in their struggles.

Looking at families from a strengths perspective, the social worker will spend little time trying to understand what caused the problem and rather focus on identifying or uncovering strengths, and create a mindset to look at positives. According to Rapp (1998:47), a shift in paradigms from a pathology orientation to a strengths and resilience focus allows for a different way of thinking about clients. It uncovers strengths and powers within clients. This paradigm shift furnishes the social worker with new and creative ways to work with families that honour their skills, competencies and talents, as opposed to their deficits. These strengths include survivor's pride, hope for the future, the ability to understand another's needs and perspectives, and the ability to identify and make choices about individual and family goals (Early \& GlenMaye, 2000:123). Marsh (2003:147) writes: "Social Work practitioners and researchers have an important role to play in advancing family strengths research. We are well-positioned to contribute to family strengths research - especially in the areas of articulating a broad and inclusive definition of family structure and family strengths; building on practice experience to document the processes and relationships that characterize strong families; and conducting policy and programme evaluation studies to document the effectiveness of specific interventions for families".

With regard to this study, the researchers attempted to find answers to the following questions:

- What is the nature of poverty in a deep rural area?

- What is the effect of poverty on these families?

- What are the families' strengths and abilities to deal with their circumstances?

- What role can the social worker play to empower these families?

\section{AIM}

The aim of this part of the project was to investigate poverty in a deep rural community and the role of social workers to empower the families.

The project pursued the following objectives:

- To examine the nature of poverty in a deep rural area;

- To investigate the effect of poverty on these families;

- To examine the strengths and abilities these families have to deal with their circumstances;

- To investigate the role of the social worker in empowering these families. 


\section{RESEARCH METHODOLOGY}

\section{Research design}

The research design can be seen as the arrangement of conditions for collecting and analysing data (Anderson, 2002:10). The study was of a cross-sectional nature, seeing that interviews were conducted with the households in the sample of the population (Rubin \& Babbie, 2005:127). The fact that the researchers wished to gain an insight into the real needs and the reasons for the poverty of the inhabitants in this particular area, the study can be described as being of a descriptive nature (Monette, Sullivan \& DeJong, 2005:5; Morris, 2006:27; Rubin \& Babbie, 2005:124-125).

Although much has been written on poverty, there is still a need to gain insight into the way disadvantaged communities are able to survive in these circumstances. There is a tendency to focus on deficits and problems and not on strengths while doing social work with families in disadvantaged communities (Ryke et al., 2008:18; Saleebey, 2002:16). The researchers also explored strategies that could be implemented to address the problem. This was a quantitative study in which the numerical data from the sample were used to generalise the findings to the larger population (Maree \& Pietersen, in Maree, 2007:145). Some qualitative open-ended questions were included in the questionnaire with a view to supporting the quantitative data and to elaborate on them to gain more insight into the phenomenon under study.

\section{Research participants}

The population consisted of the 700 households in Heuningvlei, a village in the Northern Cape Province just beyond the borders of the North-West Province, some $150 \mathrm{~km}$ from the town of Vryburg on the way to Kuruman. A random sample (Gravetter \& Forzano, 2003:119-121; Strydom, in De Vos, Strydom, Fouché \& Delport, 2005:196-197), in which every person has the same chance of being included in the study, was drawn; 230 households were selected. This can be regarded as a good representation of the total population.

The sample was taken from the population by starting at a random point, namely the nearest house to the entrance of the community. From there on, every third house was included. The head of the household or the next person in charge was requested to answer the questions in the schedule. If no one was home at a specific house, the researcher went to the house to the left of the one originally chosen.

\section{Measuring instrument}

For the purposes of this study a survey was conducted and data collected by means of semistructured one-on-one interviews in which a survey schedule was completed by the researchers (Greeff in De Vos et al., 2005:296-297). The researcher compiled the schedule after having studied similar survey schedules (Makhubele, 2004:184-192; Raath, 2001:249-261; Strydom, 2002:395-399). Once the schedule had been compiled, a pilot study was also undertaken in order to enhance the reliability and validity of the study. The schedule mostly contained closedended questions complemented by a few open-ended questions to gain more insight into the closed-ended questions. Below are examples of two closed-ended questions and two openended questions: 
Does your household have one or more of the following?

\begin{tabular}{|l|l|c|c|c|c|}
\cline { 3 - 5 } \multicolumn{2}{l|}{} & Yes & & No & \\
\hline 15.1 & Electricity & & 1 & & 2 \\
\hline 15.2 & Radio & & 1 & & 2 \\
\hline 15.3 & Television & & 1 & & 2 \\
\hline 15.4 & Telephone (land line) & & 1 & & 2 \\
\hline 15.5 & Cell phone & & 1 & & 2 \\
\hline 15.6 & Refrigerator & & 1 & & 2 \\
\hline 15.7 & Washing machine & & 1 & & 2 \\
\hline 15.8 & Personal computer & & 1 & & 2 \\
\hline
\end{tabular}

\section{If you answered yes, what kind of grant? Yes/No}

\begin{tabular}{|l|l|l|l|l|l|}
\cline { 3 - 5 } \multicolumn{1}{l|}{} & Yes & & No & \\
\hline 17.1 & Child grant & & 1 & & 2 \\
\hline 17.2 & Disability grant & & 1 & & 2 \\
\hline 17.4 & Foster-care grant & & 1 & & 2 \\
\hline
\end{tabular}

What do you see as your family's strengths?

How does your family survive in spite of unemployment and poverty?

A pilot study was undertaken by interviewing 12 persons from the same community who were not to be included in the main enquiry. The pilot study enabled the researchers to modify some questions so as to measure what was supposed to be measured and to consistently measure for the same results. This process continued until the researchers were certain that the schedule measured in a valid and reliable manner (Alston \& Bowles, 2003:47-51; Babbie, 2007:143149; Glicken, 2003:90-91; Grinnell \& Unrau, 2008:403).

\section{Procedures}

The researchers visited the identified research site beforehand to gain permission from the tribal chief, Mr Bareki, to enter the community to befriend them in order to get accustomed to the strangers there and to ascertain their willingness to participate in the study. Arrangements for accommodation for the research team were also made on this occasion. The recruitment of a number of interpreters to help with the translations into English was also done. The total research team, consisting of the main researchers, the postgraduate students and the interpreters, also spent an afternoon together in a workshop to receive training on the logistics of the study and on the completion of the survey schedule. The total team also practised completing the schedule on one another under supervision of the main researchers.

\section{Ethical aspects}

The proposal for the total Tshwaragano project was submitted to the Ethics Committee of the North-West University, Potchefstroom Campus. Permission was granted to undertake this project (with the ethics number 06K07). The ethical aspects pertaining to the study were dealt with in the following manner (Jackson, 2003:262-270; Rubin \& Babbie, 2005:70-80).

The principle of confidentiality and anonymity was observed throughout the study and no identification particulars were required. The right to privacy was also adhered to by ensuring that the interview took place in the most private area of the household. 
All possible forms of physical and emotional discomfort were combated by conducting interviews in the most suitable and comfortable surroundings possible, taking the circumstances into consideration. The length of interviews and the level of the participants' understanding were also taken into consideration.

The research team took seriously the issue of informed consent. During a meeting in the community hall where the potential participants were present, the goals and procedures of the intended study were discussed to put the community at ease about the study. A message was also conveyed to them informing them about how their participation in the study can contribute to the betterment of the community. Every participant also had to complete and sign a consent form.

The participants who needed some debriefing or needed more information on the study were welcome to speak to any member of the research team.

After completion of each interview the particular household received a two-kilogram packet of Soya as a token of appreciation for their participation in the study.

\section{Data analysis}

The data were analysed by the Statistical Consultation Services of the North-West University (Potchefstroom Campus). The program, SAS System for Windows Release 9.2 TS Level 1MO, was used to analyse the closed-ended questions (SAS Institute, 2005). The researchers analysed the data of the closed-ended questions by arranging, classifying and grouping the data into certain categories. Categories were grouped into some main areas and were mostly indicated by a percentage in order to point out the frequency of a specific category.

\section{LIMITATIONS OF THE STUDY}

The following limitations were experienced during the study:

- Extreme weather conditions, which included hot temperatures above $35^{\mathrm{C}}$ and thunder showers, made working conditions very difficult for the research team.

- The fact that most of the respondents only spoke Setswana and that the survey schedule was in English hampered comprehension and interpretation of certain questions. Although the interpreters were very helpful, they displayed little sensitivity and interrupted, omitted, substituted and added information (Ellis, 1999:97).

\section{RESULTS}

The empirical data were organised in accordance with the sequence of the survey schedule and the data will be discussed as outlined below.

\section{Identifying particulars of respondents}

The majority of the 230 respondents (49.34\%) were people aged between 31 and 50 years.

Of the respondents, $21.40 \%$ were male and $78.60 \%$ female. The female respondents were significantly more than the males. This could be as a result of more women staying at home and men searching for work or working. It could also have been because of the increase in femaleheaded households.

According to the findings, the majority of respondents (76.32\%) were single, with only $23.68 \%$ indicating that they were married. Hartman and Laird (1983:30) explain that "a family consists of two or more people who have made a commitment to share living space, have developed close emotional ties, and share a variety of family roles and functions". In Heuningvlei all the 
households $(100 \%)$ functioned as families, although individuals were not legally married or always biologically related.

The majority of the respondents $(69.78 \%)$ indicated that they either had no formal education or only primary education. The Green Paper on Population Policy (1995) reports that an estimated $50 \%$ of the rural population were illiterate at that time compared to $38 \%$ in urban areas (South African Communication Service, 1996:317). Bernstein and Gray (1997:114) confirm that illiteracy is much higher in rural areas of South Africa and it plays an important role in poverty and the low level of entrepreneurship. In responding to a question on the causes of poverty, $75 \%$ of the respondents indicated that a low level of education made it difficult to obtain employment.

Du Plessis (2006:6) emphasises the fact that South African rural schools are in a depressing state. This also is the situation at the school in Heuningvlei. The standard of education is very low, which leads to youths being unable to find employment, even with a Grade 12 certificate. According to Schenck (2004:160), a low level of education made people uninformed, dependent and disempowered. They could not really hold a job, make informed decisions or claim their rights.

All respondents were Setswana-speaking, as it is the language mostly spoken in that area of the North-West Province.

\section{Living conditions}

In this section the living conditions of the community were examined with a view to demonstrating the circumstances the people in this rural area were living in.

From the findings it is obvious that most respondents (97.29\%) lived in traditional huts, which were built of mud and bricks. These houses were not strong and were easily destroyed by strong winds or heavy rains. However, their appearance was neat, unlike shacks in urban areas.

The findings show that the majority of respondents (96.07\%) had access to clean water from public taps, even though some had to travel far to fetch it. The basic need of this community was met by the government's promise that there would be access to clean water. The only problem was that there were no water taps inside the houses. Approximately 3.5 million people in South Africa have no access to clean running water (Tempelhoff, 2006:5).

The findings indicate that the majority of respondents (97.74\%) had pit latrines which they dug themselves. The inhabitants of Heuningvlei form part of the 15 million people in South Africa who have no access to sanitation (Tempelhoff, 2006:5).

The findings indicated that the average number of people in the household was five (5). Some households accommodated up to twenty (20) people. It is evident that most houses are overcrowded, seeing that most of them have only two rooms. Many poor families co-reside because of housing costs (Miller-Cribbs \& Farber 2008:47). Miller-Cribbs and Farber (2008:47) and Schoeman (1979:113-116) point out that overcrowding can lead to a lack of privacy, sharing of scant resources, frustration and strained relationships.

The respondents indicated that only $3.93 \%$ of the inhabitants never go to bed hungry, while $61.14 \%$ of the people in the community indicated that they often go hungry. This could be a result of lack of employment, or of not having food gardens. Respondents indicated that their daily diet consisted of porridge, bread, tea, rice, cabbage and coffee. Very few respondents indicated that they included meat, poultry, vegetables or fruit in their diet. Hence it is clear that malnutrition posed a problem in the community, as they did not eat balanced meals. 
From the findings that $70 \%$ of the households had electricity it is evident that even people in the rural areas have been reached and provided with electricity. This figure compares well with the rest of the South African population, since Statistics South Africa found that seven out of ten households have electricity (Van Eeden, 2003:15).

The respondents were asked to indicate what their households used for cooking and heating. They could indicate more than one method. Only $2.64 \%$ of the respondents indicated that they used coal for cooking, $7.49 \%$ used gas, $30.40 \%$ paraffin, $49.34 \%$ electricity, while $88.99 \%$ of the respondents mentioned that they made use of wood. Although electricity was available, they made use of wood because they had no money to buy the electricity coupons.

Only a small number of households had appliances, for example, 26.96\% had television sets, $47.39 \%$ had cell phones, and $38.70 \%$ had refrigerators compared to that indicated by the average household in South Africa, namely television sets $77.0 \%$; cell phones $56.3 \%$ and refrigerators $70 \%$ (Newmarch, 2007:4). Only 38.26\% of households in Heuningvlei had radios, $2.17 \%$ washing machines and $0.87 \%$ personal computers. This could be an indication of the level of poverty, since most people in South Africa have these appliances to make life easier for themselves.

\section{Income of household}

Only $37(17.62 \%)$ of the households included someone who was employed. Vorster and De Waal (2008:236) maintain that the largest contributor to household poverty in South Africa is the high rate of unemployment. According to Statistics South Africa, the unemployment figure in South Africa is $41.6 \%$, with unemployment among black people being $50.2 \%$ (Van Eeden, 2003:15).

A percentage of 77,39 households received social grants from the government. Approximately seventy percent (70.94\%) of these were Child Support Grants (R240), 11.82\% Disability Grants (R1 010); 1.48\% Foster-Care Grants (R680) and 25.12\% Old-Age Pensions (R1 010). The amounts of the grants are confirmed by Manuel (2009:4).

It is of great concern that almost the entire community was dependent on grants. By 2008 over 12 million people were beneficiaries of grants in South Africa, including over seven million children. This represents more than $22 \%$ of the South African population (Vorster \& De Waal, 2008:234).

\section{Poverty}

- Causes of poverty

The respondents were asked what they thought the causes of poverty in their community were, and they responded as follows (they could indicate more than one):

TABLE 1

CAUSES OF POVERTY

\begin{tabular}{|l|c|c|}
\hline Causes of poverty & Frequency & \% \\
\hline Low level of education & 171 & 75.00 \\
\hline Lengthy unemployment & 180 & 78.95 \\
\hline No job opportunities & 217 & 95.18 \\
\hline Low income & 177 & 77.63 \\
\hline High fertility rate & 119 & 52.19 \\
\hline
\end{tabular}


It is evident from these responses that unemployment was the main reason why the community was poor. Because the road between Heuningvlei and the nearest large town, Ganyesa, is in a poor condition and because of a lack of infrastructure, very few job opportunities were available.

\section{- Effects of poverty}

The respondents were asked what the effect of poverty was on their families (they could indicate more than one):

TABLE 2

EFFECTS OF POVERTY

\begin{tabular}{|l|c|c|}
\hline Effects of poverty & Frequency & \% \\
\hline Ill health & 130 & 57.02 \\
\hline Malnutrition & 181 & 79.39 \\
\hline Unhealthy accommodation & 137 & 60.09 \\
\hline Family members driven to crime & 111 & 48.68 \\
\hline Children go on street & 106 & 46.49 \\
\hline Substance abuse & 114 & 50.00 \\
\hline Family disorganisation & 104 & 46.93 \\
\hline Low self-esteem & 133 & 58.33 \\
\hline Limited educational opportunities & 164 & 71.93 \\
\hline Thoughts of suicide & 70 & 30.70 \\
\hline Chronic depression & 101 & 44.49 \\
\hline
\end{tabular}

It is evident from Table 2 that poverty causes problems ranging from malnutrition to substance abuse. This is also supported by the study by Schenck (2004:158-160) in which she asked social workers in the rural areas to list the problems. They mentioned HIV/Aids, illiteracy, ill health, malnutrition, alcohol and drug dependency, marital conflict, domestic violence and crime.

Financial stability means that a sufficient income is sustained, which in turn ensures that basic needs such as food, shelter and clothing are satisfied. If the parents are unable to support the family system financially, there is a low standard of living, accompanied by a shortage of food, housing and medical care (South African Council for Social Work, 1997:136). This can lead to ill health and malnutrition. Poor families have a strong dependence on others (South African Council for Social Work, 1997:136), which in turn makes them feel inferior, leading to low self-esteem. Because they do not feel good about themselves, they tend to have thoughts of suicide. They also lack the confidence to perform well. This is especially true for children, who become uninterested in school work and are more likely to go onto the streets and engage in abuse substance. Poverty is also seen as a contributing factor to social disorganisation; therefore unfavourable economic and social circumstances can lead to delinquent behaviour (Gibson-Cline, 2000:221). 


\section{Unemployment}

\section{- Causes of unemployment}

The respondents were asked what factors they thought contributed to the high level of unemployment in their community, and they responded as follows (they could indicate more than one):

TABLE 3

CAUSES OF UNEMPLOYMENT

\begin{tabular}{|l|c|c|}
\hline Causes of unemployment & Frequency & \% \\
\hline Lack of education & 169 & 74.12 \\
\hline Illiteracy & 161 & 70.93 \\
\hline Lack of skills & 189 & 82.89 \\
\hline Ill health & 80 & 35.09 \\
\hline To old & 48 & 21.05 \\
\hline To lazy & 49 & 21.49 \\
\hline Few job opportunities & 218 & 95.61 \\
\hline
\end{tabular}

According to the respondents, the main reason for the high unemployment figure was a lack of job opportunities. Clover and Darroch (2005:241) maintain that necessary services for business survival and growth include access to water, serviceable roads, telecommunication and postal services. Heuningvlei is an isolated community in a semi-arid region with very few natural resources. Large companies are not prepared to invest money in such an unpromising region.

\section{- Problems resulting from unemployment}

The following responses to the question regarding what they thought the effect of unemployment was on the community were received (they could indicate more than one):

TABLE 4

PROBLEMS RESULTING FROM UNEMPLOYMENT

\begin{tabular}{|l|c|c|}
\hline Problems resulting from unemployment & Frequency & \% \\
\hline Conflict in home & 173 & 75.22 \\
\hline Physical violence & 137 & 59.57 \\
\hline Family breakdown & 171 & 74.35 \\
\hline Substance abuse & 163 & 70.87 \\
\hline Crime & 159 & 69.13 \\
\hline Depression & 149 & 64.78 \\
\hline Gangs & 106 & 46.09 \\
\hline Lack of self-esteem & 150 & 65.22 \\
\hline Financial problems & 219 & 95.22 \\
\hline Prostitution & 111 & 48.26 \\
\hline
\end{tabular}

From the above-mentioned responses it is clear that unemployment affected the families negatively. Because people were unemployed they stayed at home most of the day, became bored and were then inclined to resort to alcohol and drug abuse. This in turn led to conflict in the home. Crime and prostitution were illegal ways in the community to obtain money. According to Dissel (1999), Shaw (2002:151) and Strydom, Van den Berg and Herbst 
(2006:75), social problems such as poverty and unemployment can possibly also contribute to the extent of crime. Therefore the focus is on poverty eradication to raise the standard of living of disadvantaged communities.

\section{Strengths in the families}

The families in Heuningvlei were asked to describe their strengths and abilities to deal with their circumstances. Their narratives produced seven categories. These categories are discussed below.

\section{Caring and closeness}

The majority of household heads $(59.57 \%)$ mentioned that closeness among family members was a strength. They wanted their family to be available to share positive as well as negative aspects of their lives. The family members liked spending time together, such as working and doing household chores together. It was important for them to stand together and support one another in difficult times. "We stick together and care for each other." They appreciated and trusted each other.

\section{Commitment}

A percentage of 48,69 respondents felt that strong families are committed to the family and value the things that make their family special. They are able to be there for one another in good and in bad times. As a family they do not give up, even when they experience difficult times. "We love each other."

\section{Open communication}

A percentage of 12.60 mentioned that strong families communicate their feelings and are able to share with one another. They share their hopes, dreams, fears, joys, sorrows and needs. "We talk about problems openly and then try to solve them together." They also felt that a sense of humour helped.

\section{Spirituality}

Strong families share a belief in something greater than themselves, according to $53.91 \%$ of the household heads. They believe in God as he gives them hope. They like to attend church and to pray regularly. "The church is the only place where we can receive help." Shared values give families purpose and help them unite in striving for better things.

\section{Community and family ties}

Strong families are connected to others in the community, according to $11.30 \%$ of the respondents. They are closely involved with extended families and friends, schools, churches and local organisations. They are not shy to ask for assistance from the community. A percentage of 10.86 said that they buy on credit from other community members. In a study conducted by De Koker, De Waal and Vorster (2006), 83\% of poor households indicated that in times of financial difficulty they turn to friends, neighbours or family. "We teach our children to have respect for the family and the community." "The aunt keeps the family together."

\section{Entrepreneurs}

Although this is done on a very small scale, $20.86 \%$ of the respondents said they sell products such as fruit or sweets to obtain an income. A few also mentioned that they occasionally do handiwork in the community. 


\section{Future perspective}

A small percentage of the respondents (17.39) said they have hope for the future. "We believe that it will get better." A percentage of 12.17 was of the opinion that the government will help them.

\section{ROLE OF THE SOCIAL WORKER}

The respondents were asked in what way the social worker could support them, and their responses are indicated in Table 5 below (they could indicate more than one):

TABLE 5

SOCIAL WORK SUPPORT

\begin{tabular}{|l|c|c|}
\hline Type of support & Frequency & \% \\
\hline Provide material assistance & 182 & 79.82 \\
\hline Help to obtain grants & 208 & 91.23 \\
\hline Regular visits & 171 & 78.08 \\
\hline Provide information on resources & 170 & 77.63 \\
\hline Refer to resources & 168 & 73.68 \\
\hline Give advice on how to solve problems & 188 & 82.46 \\
\hline HIV/Aids counselling & 159 & 72.60 \\
\hline Marriage counselling & 111 & 48.68 \\
\hline Start income-generating projects & 206 & 90.35 \\
\hline Start social clubs & 155 & 67.98 \\
\hline Teach life skills & 195 & 85.53 \\
\hline
\end{tabular}

From the statements above it is clear that the families had a great need for services rendered by the social workers. The majority welcomed all the services.

The fact that such a large percentage indicated that they would like to receive material assistance and help in obtaining grants is of great concern. In other words, their ability to survive financially depended on what material assistance they received. The first two objectives of this research focused on the poverty of these families. From this exploration it was found that the families experience their living world mostly in terms of problems. The problems they singled out centred on basic needs and social support issues. However, when the families were asked what their strengths were, they could mention a few.

In Heuningvlei there are no non-governmental organisations or social workers who work there on a regular basis. The community urgently needs the services of a social worker who will help families and the community to take action, access resources, learn skills and practise behaviours that they have collaboratively decided will improve their lives. Social work is there to help the destitute and assist them to emerge from their state of dependence and become empowered (Mitchell, 1981:8-9; Strydom \& Tlhojane, 2008:35).

To assist the family in reaching its potential, while identifying and implementing a solution to the problems, the social worker takes on a variety of intervention roles (Compton \& Galaway, 1999:309).

\section{Social broker}

A social work broker links the client with other community resources to accomplish objectives. This requires a broad knowledge of community resources so that the social worker can help the 
family find and use a needed resource (Compton \& Galaway, 1999:309). According to Table 5, the majority of the respondents $(77.63 \%)$ indicated that they would like the social worker to provide information on resources.

The social worker should liaise with relevant stakeholders in the Province who could supply the community with help and information. For instance, the Department of Labour could be asked to present job training. The Department of Education could teach members of the community to care for pre-school children. Attention should be given to the training of teachers so that the standard of education in Heuningvlei can be lifted. The Department of Arts and Culture could teach the women sewing and baking skills, which could help them to earn some money. The Department of Agriculture should be consulted about sustainable projects that could be developed in the community. For instance, if a need for a food garden is expressed by the community, the role of the worker should be to bring the community into contact with the agricultural extension officer responsible for the area (Swanepoel \& De Beer, 2007:163). The Department of Micro-biology at the University was prepared to help the community to plant marog, a very hardy cultivar. The Department of Correctional Services could arrange a day in which residents are lectured on crime prevention. Most of the respondents mentioned that the church helps them to survive and therefore the social worker could advise the church on the best way to care for the families.

\section{Enabler}

Social work and social workers have long been concerned with families. Historically, most approaches to social work with families have focused on individual pathology and problem solving, or have considered problems of a family member to be symptoms of family dysfunction (Early \& GlenMaye, 2000:118).

In the enabler role, the social worker assists clients in finding the coping strengths and resources within themselves to produce the changes required by the objectives (Compton \& Galaway, 1999:31). The social worker should identify the strengths of the people in Heuningvlei and try to develop them.

A strength that was identified by the families themselves was that they were committed, caring and close families. Therefore the social worker should encourage the family to work together and to provide mutual support for one another (Miller-Cribbs \& Farber, 2008:49). Although the family said that open communication was a strength, techniques in communication and dealing with conflict at an elementary level should be implemented for the families. They should motivate one another to improve themselves. For example, they could cultivate a food garden as a family, where each member has a role to play from planting seeds, irrigating the land to selling the products. Such talents, be it cooking, baking bread or tending to the needs of the ill, may become tools for helping to build a better life.

Another strength which was mentioned was their strong community ties. The social worker can therefore encourage the family to become actively involved in the community and take pride in the community.

\section{Teacher}

In the teacher role, the social worker provides families with new information necessary for coping with problem situations, assisting families in practising new behaviours or skills or modelling alternative behaviour patterns (Compton \& Galaway, 1999:311). According to Table $5,85.53 \%$ of the respondents said that they wanted the social worker to teach them skills. It is 
recommended that the social worker should provide workshops during which the community members are taught various skills and techniques, including survival skills and managing their funds or money, and also present workshops on project management. The social worker should present programmes on life skills development. If they feel good about themselves, they will be more willing to embark on adventures. If peoples' low sense of power is addressed by means of programmes, development work will have a greater chance to succeed (Ryke, 2004:101-104).

As a teacher the social worker can provide HIV/Aids counselling that will equip the family members with knowledge to be able to stand up against the challenges of the epidemic. A group work programme to empower HIV/Aids-affected, poverty-stricken families with themes such as life skills, HIV and Aids, positive living, parent training and closure could be presented.

To understand peoples' experiences within their socio-cultural context, the services of a person who is knowledgeable about the community should be utilised to support the social worker become familiar with the community and its people. An auxiliary worker could be considered for this purpose.

\section{Mediator}

In the mediating role the social worker assists families and the other party to find common ground on which to resolve the conflict (Compton \& Galaway, 1999:311). The social worker should be a peacemaker between different parties, especially concerning the rendering of services by the municipality. Some of the participants told the researchers they were very unsatisfied with the poor infrastructure of the community and that the social worker must hold talks with both parties.

\section{Advocate}

As an advocate, the social worker presents and argues the family's cause, when necessary, in order to help them become empowered (Compton \& Galaway, 1999:312). The social worker should speak to the chief of the village on behalf of the community members concerning a small plot/land to develop a project.

\section{Empowerer}

A key goal of social work practice is empowerment, which is the process of helping families increase their personal, interpersonal, and socio-economic and political strength and influence through improving their circumstances (Zastrow, 2004:78). The social worker should show the people that he/she believes in their ability to do something about their needs (Swanepoel \& De Beer, 2007:163).

The social worker should become involved in the community and empower the families to take part in sustainable developments. For as long as there are no resources or no development in the community, there will be no improvement in the quality of life. The community should be empowered to become self-reliant and not be dependent on grants.

The members of the community should be active in the entire process, from identifying the problem, developing and enhancing strengths, initiating programmes to evaluating the outcomes of programmes. Peu, Van Wyk and Botha (2008:15) argue that it is not sufficient for the providers to engage in activities without consultation with, and the involvement and participation of, individuals and families. 
Women and children in the community should be empowered to know what their rights are and to stand up to abuse against them. In the context of a history of violence, often extending over many years, and all the while eroding and destroying self-esteem and self-determination, it is essential to understand that effective help must be directed towards enabling the woman to take control of her own life. The aim should be to offer her realistic choices, while accepting that the decisions are hers alone and are always valid in her particular situation. Her autonomy should be encouraged (Keeling \& Mason, 2008:171).

Table 5 reveals that the majority of respondents $(67.98 \%)$ said that they would like the social worker to establish social clubs. Clubs that empower youths need to provide opportunities for development at both individual and community levels. These should be opportunities that provide them with stronger ties to the community, a greater understanding of other people's needs and a commitment to making that community a better place to live in (Jennings, ParraMedina, Hilfinger Messias \& McLoughlin, 2006:49). Young people should be encouraged to become entrepreneurs and earn an income so that crime does not become an option.

According to Scheve, Perkins and Mincemoyer (2006:220), there should be opportunities for young people to engage in their communities, because with their energy, they can reinvigorate adults and organisations by approaching challenges with a fresh perspective and offering creative solutions.

\section{CONCLUSION}

Even though the families indicated that poverty causes conflict in the home and family breakdown, the respondents felt that the family was their most important strength. They valued the closeness and commitment to one another very highly. Families have the capacity for growth and change and to adapt. They also have many capabilities, abilities and strengths. In some way or another they survive despite huge challenges. For the sake of these families' wellbeing and happiness, it is important that they should be empowered and that their strengths are accepted and enhanced. The social worker is the person who can empower them.

A study such as this may contribute to a better insight into the world in which families have to live and survive today, but also into the structure and functioning of families in South Africa. Healthy families will help to build healthy communities in the future and this will benefit everyone in the country.

\section{REFERENCES}

ALSTON, M. \& BOWLES W. 2003. Research for social workers: an introduction to methods. New York: Routledge Taylor \& Francis Group.

ANDERSON, W.W. 2002. Social work research notes. Mmabatho: University of North West. BABBIE, E. 2007. The practice of social research. New York: Thomson Wadsworth Publishers.

BARNETT, T. \& BLAIKIE, P. 1992. Aids in Africa: its present and future impact. London: Belhaven Press.

BERNSTEIN, A. \& GRAY, M. 1997. Social work: a beginner's text. Durban: Juta \& Co.

CLOVER, T.A. \& DARROCH, M.A.G. 2005. Owners' perceptions of factors that constrain the survival and growth of small, medium and micro agribusinesses in KwaZulu-Natal, South Africa. Agrekon, 44(2):238-263. 
COMPTON, B.R. \& GALAWAY, B. 1999. Social work processes. New York: Brooks/Cole.

DE KOKER, C., DE WAAL, L. \& VORSTER, J. 2006. A profile of social security beneficiaries in South Africa. Commissioned research for the Department of Social Development. Stellenbosch: Data desk and Department of Sociology and Social Anthropology, University of Stellenbosch.

DE VOS, A.S., STRYDOM, H., FOUCHÉ, C.B. \& DELPORT, C.S.L. (eds) 2005. Research at grass roots for the social sciences and human service professions. Pretoria: Van Schaik Publishers.

DISSEL, A. 1999. Children serving goal sentences: a profile on children sentenced to prison. [Online] Available: http//www.wits.ac.za/csvr/papers/papdis7htm. [Accessed: 10/08/ 2005].

DU PLESSIS, C.A. 2006. The development of a coping and life skills programme for adolescents in a rural area. Potchefstroom: North-West University. (MA Dissertation)

EARLY, T.J. \& GLENMAYE, L.F. 2000. Valuing families: social work practice with families from a strengths perspective. Social Work, 45(2):118-129.

ELLIS, C. 1999. Learning language and culture in the medical consultation. South Africa: Parke-Davids.

GIBSON-CLINE, J. 2000. Youth and coping in twelve nations: surveys of 18-20 year old young people. New York: Routledge.

GLICKEN, M.D. 2003. Social research: a simple guide. New York: Allyn and Bacon.

GRAVETTER, F.J. \& FORZANO, L.B. 2003. Research methods for the behavioral sciences. New York; Thomson Wadsworth.

GRINNELL, R.M. \& UNRAU, Y.A. 2008. Social work research and evaluation: foundations of evidence - based practice. London: Oxford University Press.

HARTMAN, A. \& LAIRD, J. 1983. Family-centered social work practice. New York: Free Press.

JACKSON, S.L. 2003. Research methods and statistics: a critical thinking approach. New York: Thomson Wadsworth.

JENNINGS, L.B., PARRA-MEDINA, D.M., HILFINGER MESSIAS, D.K. \& McLOUGHLIN, K. 2006. Toward a critical social theory of youth empowerment. Journal of Community Practice, 14(1/2):31-55.

KEELING, J. \& MASON, T. 2008. Domestic violence: a multi-professional approach for healthcare practitioners. New York: Open University Press.

MAKHUBELE, J.C. 2004. The impact of culture on the prevention and treatment of HIV/Aids amongst people in low-resourced areas: a social work perspective. Pietersburg: University of the North. (MA Dissertation)

MANUEL, T. 2009. Welsyntoelae kry stewige hupstoot van R13.2 miljard. Beeld, February 12:4.

MAREE, K. (ed) 2007. First steps in research. Pretoria: Van Schaik Publishers.

MARSH, J.C. 2003. Arguments for family strengths research. Social Work, 48(2):147-150. 
MILLER-CRIBBS, J.E. \& FARBER, N.B. 2008. Kin networks and poverty among African Americans: past and present. Social Work, 53(1):43-51.

MITCHELL, W.A. 1981. Poverty and social work. Grahamstown: Rhodes University.

MONETTE, D.R., SUlLIVAN, T.J. \& DEJONG, C.R. 2005. Applied social research: tool for the human services. New York: Thomson Brooks/Cole Publishers.

MORRIS, T. 2006. Social work research methods: four alternative paradigms. London: Sage Publishers.

MSINDISI, M. 2000. An investigation into the relationship between poverty and family size in South Africa through the analysis of 195 October Household survey. Pretoria.

NEWMARCH, J. 2007. Black share of income now highest. Mail \& Guardian, 31 October.

PATEL, L. 2005. Social welfare and social development in South Africa. Cape Town, South Africa: ABS Press Publishers.

PEU, M.D., VAN WYK, N.C. \& BOTHA, A.D.H. 2008. Health promotion needs of Hammanskraal families with adolescents orphaned by HIV/Aids. Health SA Gesondheid, 13(1):14-28.

RAATH, H. 2001. Riglyne vir die maatskaplikewerkhantering van die psigo-sosiale behoeftes van MIV/VIGS blootgestelde adolessente. (Guidelines for social work managing of the psycho-social needs of HIV/Aids affected adolescents). Potchefstroom: PU for CHE. (MA Dissertation)

RAPP, C.A. 1998. The Strengths Model. Case management with people suffering from severe and persistent mental illness. New York: Oxford University Press.

RUBIN, A. \& BABBIE, E. 2005. Research methods for social work. Australia: Thompson.

RYKE, E. 2004. The social niche of farm dwellers: a social work strengths approach. Potchefstroom: North-West University. (PhD Thesis)

RYKE, E., STRYDOM, H. \& BOTHA, K.F.H. 2008. Towards a social niche assessment instrument. Social Work/Maatskaplike Werk, 44(1):18-33.

SALEEBEY, D. 2002. The strengths perspective in social work practice. Boston: Allyn \& Bacon.

SAS INSTITUTE. 2005. The SAS System for Windows Release 9.1 TS Level1MO. Cary, NC, USA: SAS Institute.

SCHEVE, J.A., PERKINS, D.F. \& MINCEMOYER, C. 2006. Collaborative teams for youth engagement. Journal of Community Practice, 14(1/2):31-55.

SCHENCK, C.J. 2004. Problems rural social workers experience. Social Work/Maatskaplike Werk, 40(2):158-171.

SCHOEMAN, J.H. 1979. Die taak van gemeenskapswerk in 'n swart stedelike gebied. (The role of community work in a black township). Pretoria: University of Pretoria. (DPhil Thesis)

SHAW, M. 2002. Crime and policing in post-apartheid South Africa. London: Hurst and Company.

SOUTH AFRICAN COMMUNICATION SERVICE. 1996. S.A. Yearbook. Pretoria: Government printer. 
SOUTH AFRICAN COUNCIL FOR SOCIAL WORK. 1997. Social auxiliary work. Pretoria: Government Printer.

STRYDOM, C. 2002. Evaluation of an HIV/Aids programme for students at a tertiary institution with emphasis on peer group involvement. Potchefstroom: $\mathrm{PU}$ for $\mathrm{CHE}$. (PhD Thesis)

STRYDOM, C. \& TLHOJANE, M.E. 2008. Poverty in a rural area: the role of the social worker. Social Work/Maatskaplike Werk, 44(1):34-51.

STRYDOM, H., VAN DEN BERG, K. \& HERBST, A. 2006. Perceptions of crime in disadvantaged communities: the Thusano Project. Acta Criminologica, 19(2):75-87.

SWANEPOEL, H. \& DE BEER, F. 2007. Community development: breaking the cycle of poverty. Lansdowne, South Africa: Juta \& Co.

TEMPELHOFF, E. 2006, Miljarde het nie toegang tot sanitasie. (Millions have no access to sanitation) Beeld, March 5:22.

VAN EEDEN, J. 2003. Een uit ses nie getel vir sensus. (One out of six not counted for census) Rapport, 13 July: 15.

VORSTER, J. \& DE WAAL L. 2008. Beneficiaries of the child support grant: findings from a national survey. The Social Work Practitioner-Researcher, 20(2):233-249.

WESSELS, C.C. 2003. Die opstel en evaluering van ' $n$ maatskaplikewerk bemagtigingsprogram vir gesinne van MIV-positiewe en VIGS-pasiënte. (The development and evaluation of a social work empowerment programme for HIV positive and Aids patients) Potchefstroom: PU for CHE. (PhD (SW) Thesis)

WHITE PAPER FOR SOCIAL WELFARE. 1997. Pretoria: Government Printer.

ZASTROW, C. 2004. Introduction to social work and social welfare. Belmont: Brooks/Cole.

Dr Corinne Strydom, Dr Cornelia Wessels, Prof Herman Strydom, Department of Social Work, School of Psycho-Social Behavioural Sciences, Potchefstroom Campus, North-West University, Potchefstroom, South Africa. 